\title{
Mechanical characterization and optimization of heat treatment parameters of manganese alloyed austempered ductile iron
}

\author{
Ananda Hegde ${ }^{1}$, Sathyashankara Sharma ${ }^{1 *}$ and Ramakrishna Vikas Sadanand ${ }^{1}$ \\ ${ }^{1}$ Department of Mechanical and Manufacturing Engineering, Manipal Institute of \\ Technology, Manipal Academy of Higher Education, \\ Manipal, Karnataka, India, 576104 \\ Phone: 9740540928; Fax: 91-820-2571071 \\ "Email: ss.sharma@manipal.edu
}

\begin{abstract}
Austempered Ductile Iron (ADI) belongs to the family of cast irons whose mechanical properties are altered using austempering heat treatment process. The objective of this paper is to study the effects of heat treatment parameters on manganese alloyed ADI. Hence, austenitization temperature, austempering temperature and austempering time are taken as the control variables along with the manganese content in the material. The effects of heat treatment are studied by measuring the ultimate tensile strength and the hardness of the material. The regression equations are developed to relate the various parameters under study. The microstructures of the specimen reveal that retained austenite content increases with increase in manganese and results in decrease in hardness of the material. The statistical analyses indicate that the austempering temperature is the major factor affecting the variation in hardness and tensile strength with $74.5 \%$ of contribution within the range of values whereas, variation in manganese content does not have significant effect on hardness within the investigated composition range in the material.
\end{abstract}

Keywords: Optimization; Analysis of variance; Austempered ductile iron; Austenitization ; Austempering.

\section{INTRODUCTION}

Austempered ductile iron (ADI) is a heat treated ductile cast iron with a unique microstructure known as "ausferrite" which offers superior combination of various mechanical properties [1]. The microstructure of ADI consists of acicular ferrite and carbon rich austenite (known as "ausferrite") with graphite nodules. ADI offers excellent strength, toughness and fatigue characteristics. It has high strength to weight ratio and excellent wear resistance. High austempering temperature $\left(400^{\circ} \mathrm{C}\right)$ produces ADI with high ductility, yield strength in the range of $500 \mathrm{MPa}$ with good fatigue and impact strength. A lower austempering temperature results in ADI with very high yield strength, high hardness and excellent wear resistance. The properties can be controlled and altered suitably by varying the heat treatment parameters [2-4]. The farm machinery industry has taken a keen interest in ADI for its excellent wear characteristics. The heavy truck industry has recognised the potential benefits of austempering solutions many years ago. Manufacturers took advantages 
of the versatility of ADI to introduce innovative light weight; high performance parts. Typical examples include diesel engine timing gear, suspension brackets, gear housings, wheel hubs, and sprockets [5-6].

Many authors have reported the effect of heat treatment parameters on the mechanical properties of ADI [7-10]. Various methods to produce the ADI have also been reported by few researchers. Olawale et al. [11] reported about the forced air cooling quenching to produce austempered ductile iron. It was reported that ADI of section thickness up to $25 \mathrm{~mm}$ can be produced with the use of forced air cooling quenching method. Arft et al. [12] reported about the machinability aspects of austempered ductile iron. The study revealed about the possible adoption of machining strategies to counteract the obstacles faced during the machining of ADI due to its high hardness. Basso and Sikora [13] reported about the production of dual phase austempered ductile iron. The study described the methodology used to produce dual phase ADI which is capable of replacing steel castings and forgings in many engineering applications. Zanardi et al. [14] reported about the grading system of ADI. The study includes the mechanical properties of ADI and how these properties vary with the different grades of ADI. Mendez et al. [15] compared the properties of conventionally heat treated austempered ductile iron with nodular iron having ferritic -pearlitic grades. Murthy et al. [16] reported the abrasion behaviour of manganese alloyed permanent moulded ADI. Bayati and Elliott [17] reported about the austempering process in the ADI containing 0.67 wt $\%$ manganese. It was reported that addition of high amount of manganese delays the stage I austempering reaction and also delays stage II transformation. Not much information is available regarding how the variation of manganese within the range of $0.3 \mathrm{wt} \%$ to $1 \mathrm{wt} \%$ affects the mechanical properties of the ADI. Machinability of any material is an important aspect to consider while selecting the material [18]. It is very essential to optimize the process parameters in order to obtain optimum mechanical properties and machinability.

The present study focuses on optimizing the heat treatment parameters in manganese alloyed ADI in order to obtain the optimum hardness. The present investigation selected four independent variables which are called as factors: austenitization temperature, austempering temperature, austempering time and manganese content. The hardness and tensile strength are the mechanical properties considered to be important to study the effects of changes in the factors. Manganese is varied in the lower range so as to ensure that it is fully dissolved in the matrix. A regression model is developed using Response Surface Methodology (RSM) to relate mechanical properties with the heat treatment parameters and manganese content.

\section{MATERIALS AND METHODS}

\section{Design of Experiment}

In the current study, austenitization temperature, austempering temperature, austempering time and manganese content are selected as independent variables or control factors. Austenitization time is kept constant at $2 \mathrm{~h}$ in order to focus on the effect of manganese on mechanical properties. Generally, addition of high amount of manganese forms the carbide at the intercellular region. Manganese tends to segregate at the grain boundary which produces precipitates. This adversely affects on the mechanical properties of ADI. Hence, the addition of manganese is restricted to $1 \mathrm{wt} \%$. The dependent variables are hardness and tensile strength. Mixed level design is employed and full factorial design is employed to 
analyze the various control factors and hence a total of 36 trails are conducted. The details about the design of experiments are given in the Table 1.

Table 1. Details of control factors with various levels

\begin{tabular}{cccc}
\hline Control factors & Level 1 & Level 2 & Level 3 \\
\hline Austenitization temperature & $850^{\circ} \mathrm{C}$ & $950^{\circ} \mathrm{C}$ & --- \\
Austempering temperature & $320^{\circ} \mathrm{C}$ & $370^{\circ} \mathrm{C}$ & $420^{\circ} \mathrm{C}$ \\
Austempering time & $1 \mathrm{~h}$ & $2 \mathrm{~h}$ & ---- \\
Manganese content & $0.268 \mathrm{wt} \%$ & $0.64 \mathrm{wt} \%$ & $1.01 \mathrm{wt} \%$
\end{tabular}

\section{Material}

Ductile iron was cast as per the ASTM standard A897/A897M - 15 [19]. The raw materials were melted in the medium frequency induction furnace. The required alloying elements were added to the melt followed by nodulization and inoculation. The melt was poured to the Y block mold at temperature range of $1490^{\circ} \mathrm{C}$ to $1520^{\circ} \mathrm{C}$. The manganese content was varied in three levels as low (0.268 wt\%), medium (0.64 wt \%) and high (1.01\%). The wt\% of manganese is restricted because the maximum solubility of manganese in ferrite phase is 3 wt $\%$, so that the precipitation of hard manganese carbide phase is avoided during heat treatment. The composition of all the castings and the different melts are maintained close to the composition specified in Table 2 as per the experiment design requirements. Care is taken to ensure that only manganese content is varied while keeping all other elements at the same amount so that effect of manganese on the mechanical properties can be analyzed. Tensile test specimens were machined out from the $\mathrm{Y}$ block casting according to ASTM standard E8/E8M [20]. For micro structure analyses and hardness test, the specimens were machined out from the round bars.

Table 2. Chemical composition of ductile iron casting

\begin{tabular}{ccccccccc}
\hline Type of casting\Element in wt\% & $\mathrm{C}$ & $\mathrm{Si}$ & $\mathrm{Mn}$ & $\mathrm{P}$ & $\mathrm{S}$ & $\mathrm{Cr}$ & $\mathrm{Mg}$ & $\mathrm{Fe}$ \\
\hline Low Mn & 3.70 & 2.60 & 0.268 & 0.015 & 0.013 & 0.017 & 0.0360 & 93.35 \\
Medium Mn & 3.71 & 2.60 & 0.64 & 0.015 & 0.013 & 0.017 & 0.0380 & 92.96 \\
High Mn & 3.71 & 2.59 & 1.01 & 0.015 & 0.013 & 0.016 & 0.0370 & 92.6 \\
\hline
\end{tabular}

\section{Heat treatment and Characterization}

The samples are subjected to austempering heat treatment. The samples were heated in a muffle furnace to the predetermined austenitization temperature and then held at that 
temperature for a predetermined time of $2 \mathrm{~h}$ and this holding time period is called austenitization time. The specimens were then transferred quickly to a salt bath comprising of $\mathrm{NaNO}_{2}$ and $\mathrm{NaNO}_{3}$ maintained at the required austempering temperature. The specimens were held at this austempering temperature for a time period called austempering time followed by the air cooling of the samples to room temperature. Tensile tests of these heat treated samples were carried out using a computer controlled tensometer. Hardness of all the specimens was determined using Brinell hardness method. Metallurgical microscope is used to study the microstructure of the samples which are prepared by polishing and etching the specimen using nital.

\section{RESULTS AND DISCUSSIONS}

Tensile test and Hardness test have been conducted as per the ASTM standards E8/E8M on all the test specimens prepared as per the design of experiments. The results of the same are provided in Table 3 and Table 4. The average of three test results is considered as the result for a given experiment condition and it has been found that the variation of results for a given experiment design is less than $1 \%$ in all cases. The close values of the results can be attributed to the sample preparation methods and control of process parameters.

Table 3. Hardness and tensile strength of heat treated samples at austenitization temperature $950^{\circ} \mathrm{C}$

\begin{tabular}{cccccc}
\hline $\begin{array}{c}\text { Experiment } \\
\text { No }\end{array}$ & $\begin{array}{c}\text { Austempering } \\
\text { Temperature } \\
{ }^{\circ} \mathbf{C}\end{array}$ & $\begin{array}{c}\text { Austempering } \\
\text { Time } \\
\text { Hour }\end{array}$ & $\begin{array}{c}\text { Mn } \\
\text { Content } \\
\text { wt \% }\end{array}$ & $\begin{array}{c}\text { Hardness } \\
\text { BHN }\end{array}$ & $\begin{array}{c}\text { Ultimate Tensile } \\
\text { Strength } \\
\text { N/mm }\end{array}$ \\
\hline 1 & 320 & 1 & 0.268 & 331 & 1131 \\
2 & 320 & 2 & 0.268 & 322 & 1105 \\
3 & 370 & 1 & 0.268 & 277 & 890 \\
4 & 370 & 2 & 0.268 & 271 & 835 \\
5 & 420 & 1 & 0.268 & 240 & 650 \\
6 & 420 & 2 & 0.268 & 233 & 610 \\
7 & 320 & 1 & 0.64 & 341 & 1050 \\
8 & 320 & 2 & 0.64 & 331 & 987 \\
9 & 370 & 1 & 0.64 & 276 & 815 \\
10 & 370 & 2 & 0.64 & 278 & 765 \\
11 & 420 & 1 & 0.64 & 240 & 580 \\
12 & 420 & 2 & 0.64 & 233 & 548 \\
13 & 320 & 1 & 1.01 & 330 & 950 \\
14 & 320 & 2 & 1.01 & 322 & 904 \\
15 & 370 & 1 & 1.01 & 264 & 715 \\
16 & 370 & 2 & 1.01 & 265 & 687 \\
17 & 420 & 1 & 1.01 & 233 & 490 \\
18 & 420 & 2 & 1.01 & 229 & 470 \\
\hline
\end{tabular}


Table 4. Hardness and tensile strength of heat treated samples at austenitization temperature $850^{\circ} \mathrm{C}$

\begin{tabular}{cccccc}
\hline $\begin{array}{c}\text { Experiment } \\
\text { No }\end{array}$ & $\begin{array}{c}\text { Austempering } \\
\text { Temperature } \\
{ }^{\circ} \mathrm{C}\end{array}$ & $\begin{array}{c}\text { Austempering } \\
\text { Time } \\
\text { Hour }\end{array}$ & $\begin{array}{c}\text { Mn } \\
\text { Content } \\
\text { wt } \%\end{array}$ & $\begin{array}{c}\text { Hardness } \\
\text { BHN }\end{array}$ & $\begin{array}{c}\text { Ultimate Tensile } \\
\text { Strength } \\
\text { N/mm }\end{array}$ \\
\hline 19 & 320 & 1 & 0.268 & 392 & 1410 \\
20 & 320 & 2 & 0.268 & 382 & 1377 \\
21 & 370 & 1 & 0.268 & 326 & 1179 \\
22 & 370 & 2 & 0.268 & 322 & 1120 \\
23 & 420 & 1 & 0.268 & 271 & 910 \\
24 & 420 & 2 & 0.268 & 265 & 875 \\
25 & 320 & 1 & 0.64 & 388 & 1310 \\
26 & 320 & 2 & 0.64 & 386 & 1272 \\
27 & 370 & 1 & 0.64 & 322 & 1086 \\
28 & 370 & 2 & 0.64 & 331 & 1050 \\
29 & 420 & 1 & 0.64 & 277 & 855 \\
30 & 420 & 2 & 0.64 & 270 & 810 \\
31 & 320 & 1 & 1.01 & 375 & 1210 \\
32 & 320 & 2 & 1.01 & 373 & 1175 \\
33 & 370 & 1 & 1.01 & 322 & 975 \\
34 & 370 & 2 & 1.01 & 308 & 930 \\
35 & 420 & 1 & 1.01 & 262 & 745 \\
36 & 420 & 2 & 1.01 & 264 & 724 \\
\hline
\end{tabular}

\section{Microstructure analysis}

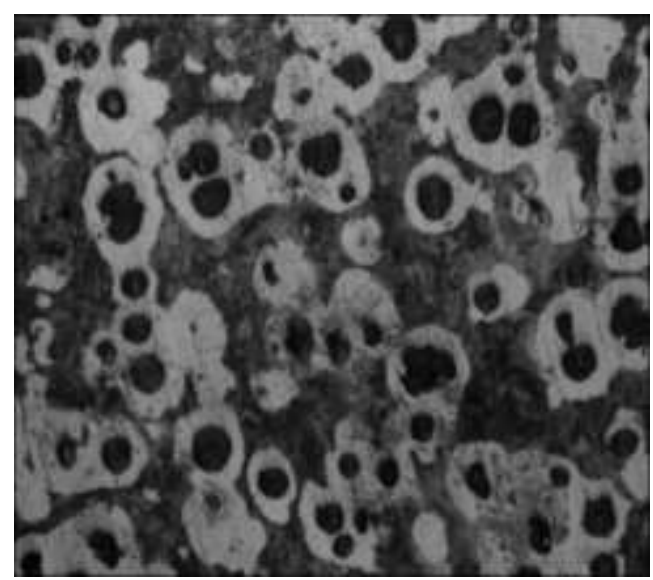

(a)

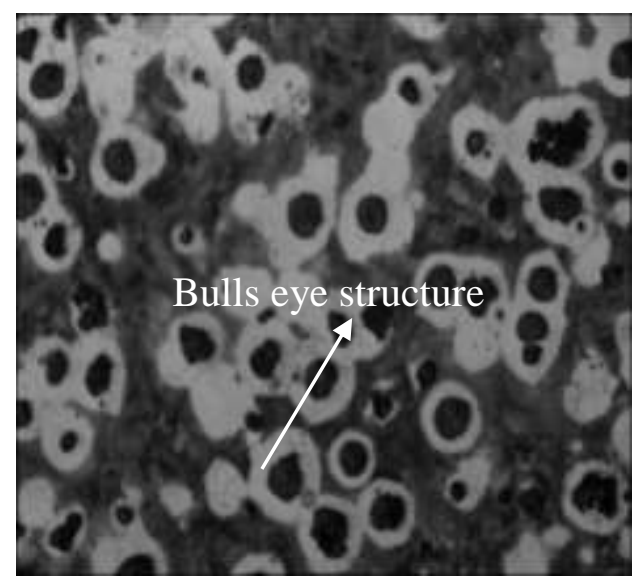

(b)

Figure 1. Microstructures of as cast ductile iron with (a) 0.64 wt \% Mn, (b) $1.01 \mathrm{wt} \% \mathrm{Mn}$ 
Figure 1 shows the microstructures of as cast ductile iron samples with different proportion of manganese content. It is observed that graphite nodules are surrounded by ferrite in the bull's eye structure. The nodule count of the samples are determined as 354 number $/ \mathrm{mm}^{2}$ for $0.64 \mathrm{wt} \% \mathrm{Mn}$ sample, and 380 number/ $\mathrm{mm}^{2}$ for $1.01 \mathrm{wt} \% \mathrm{Mn}$ sample respectively.

The microstructures of ADI specimen which are austempered for $1 \mathrm{~h}$ duration are taken for analysis since there was no difference in the mechanical properties due to change in austempering time. It is observed that most of the microstructures consisted a mixture of dark needle shaped ferrite along with retained austenite. Graphite nodules were found to be dispersed in the matrix. At lower austempering temperature of $320^{\circ} \mathrm{C}$, the very fine structure is found and the ferrite is more acicular. As the austempering temperature is increased to $420^{\circ} \mathrm{C}$, the structure became coarser with feathery ferrite. This is the upper bainitic structure with relatively coarse structure. Thus, increasing the austempering temperature resulted in coarsening of the ferrite, as well as, an increase in the retained austenite content which would lead to reduced hardness. This is in accordance with the microstructure study which has been published many authors [21-24].

The figure 2 and 3 show the microstructures of samples which had been austenitized at $850^{\circ} \mathrm{C}$ and $950^{\circ} \mathrm{C}$ respectively with different austempering temperatures and manganese content. The amount of retained austenite was measured using the metallurgical image analysis software as per the ASTM standard E1245-03 [25]. The results are shown in the table 5. From the results of the image analysis, it is observed that, as the austempering temperature and austenitization temperatures are increased, the amount of retained austenite is increased significantly. Also, there was a slight increase in the amount of retained austenite as the manganese content is varied to $1.01 \mathrm{wt} \%$ from $0.268 \mathrm{wt} \%$. This explains the very little variation in the hardness value as the manganese content is varied and hence the predominant factor affecting the hardness is austempering temperature. The optimum hardness and strength obtained even with the high amount of manganese addition may be attributed to the high nodule count. It was also evident that most of the carbides got dissolved in the matrix. At the austempering temperature of $320^{\circ} \mathrm{C}$ and austenitization temperature of $850^{\circ} \mathrm{C}$, a very fine structure is observed in the microstructure and the ferrite was found to be more acicular as shown in Figures $2 \mathrm{a}$ and $2 \mathrm{~b}$. When the austempering temperature is $420^{\circ} \mathrm{C}$ and austenitization temperature is $950^{\circ} \mathrm{C}$, an upper bainitic structure is noticed which is a coarse structure with feathery ferrite as shown in figures 3 a and $3 \mathrm{~b}$. At the high austempering temperature of $420^{\circ} \mathrm{C}$, lower hardness was resulted. Also, at the austenitization temperature of $950^{\circ} \mathrm{C}$, hardness value is slightly lower compared to the hardness at the austenitization temperature of $850^{\circ} \mathrm{C}$ due to the coarsening of the grains. This explains the moderate contribution of austenitisation temperature on the hardness. This is in accordance with the various reports which have been published [26-29]. 




(a)

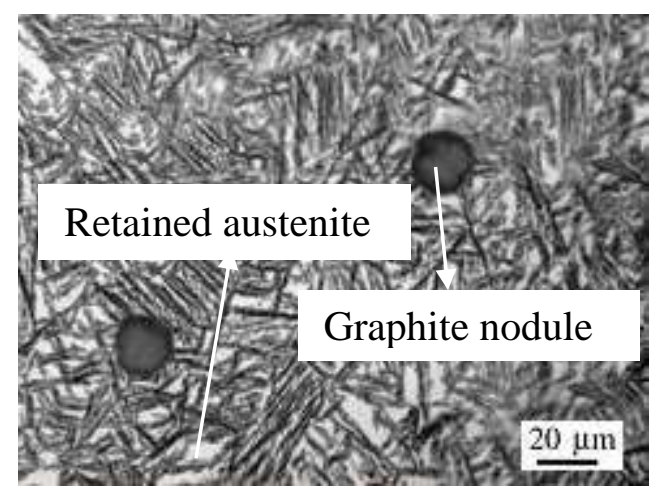

(b)

Figure 2. Microstructures of ADI austenitized at $850^{\circ} \mathrm{C}$ for $2 \mathrm{~h}$ and austempered at $320^{\circ} \mathrm{C}$ for $1 \mathrm{~h}$ with (a) $0.268 \mathrm{wt} \% \mathrm{Mn}$, (b) $1.01 \mathrm{wt} \% \mathrm{Mn}$

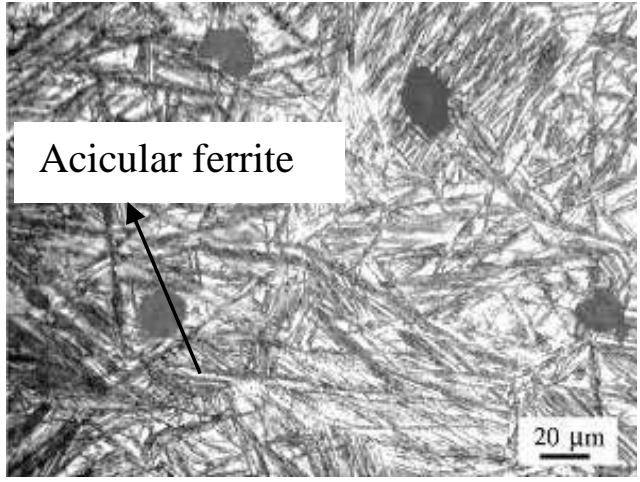

(a)

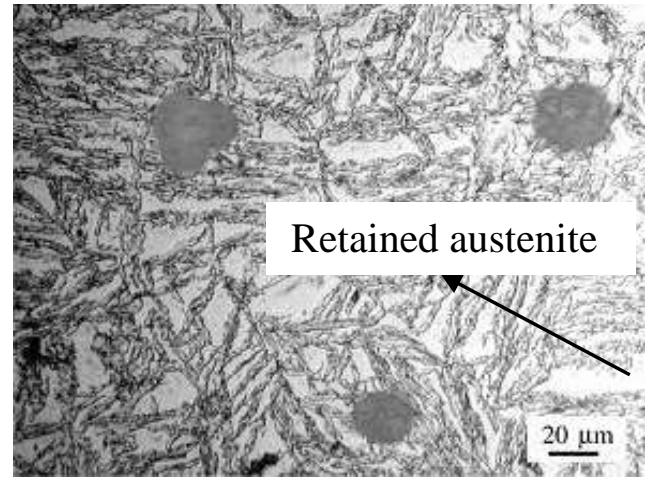

(b)

Figure 3. Microstructures of ADI austenitized at $950^{\circ} \mathrm{C}$ for $2 \mathrm{~h}$ and austempered at $420^{\circ} \mathrm{C}$ for $1 \mathrm{~h}$ with (a) $0.268 \mathrm{wt} \% \mathrm{Mn}$, (b) $1.01 \mathrm{wt} \% \mathrm{Mn}$

Table 5. Amount of retained austenite by metallurgical image analysis

\begin{tabular}{cccc}
\hline $\begin{array}{c}\text { Austenitization } \\
\text { Temperature }\end{array}$ & $\begin{array}{c}\text { Austempering } \\
\text { Temperature }\end{array}$ & $\begin{array}{c}\text { Manganese } \\
\text { Content }\end{array}$ & $\begin{array}{c}\text { Content of Retained } \\
\text { Austenite }\end{array}$ \\
${ }^{\circ} \mathrm{C}$ & ${ }^{\circ} \mathrm{C}$ & wt \% & Vol \% \\
\hline 850 & 320 & 0.268 & 24 \\
850 & 320 & 1.010 & 28 \\
950 & 420 & 0.268 & 35 \\
950 & 420 & 1.010 & 38 \\
\hline
\end{tabular}




\section{Analysis of variance (ANOVA) for hardness and tensile strength}

ANOVA was carried out, initially with all the four terms together with their interactions and it was found that the linear terms had more than $99 \%$ contribution for tensile strength and hardness. Hence, the final ANOVA analysis is carried out at 5\% significance level using only the linear terms to obtain the relative contribution of the four factors on the hardness and tensile strength. The results of ANOVA of the hardness are shown in table 6. From the results, it can be inferred that austempering temperature has the most significant effect on the hardness followed by austenitization temperature. These two factors contribute to $97.7 \%$ of the changes in the hardness in the rage of values under study. Austempering time and Manganese content do not contribute much to the variations in hardness of the material in the range of study.

Table 6. ANOVA results for hardness

\begin{tabular}{|c|c|c|c|c|c|}
\hline Factors & $\begin{array}{l}\text { Degrees of } \\
\text { freedom }\end{array}$ & $\begin{array}{l}\text { Seq sum of } \\
\text { square }\end{array}$ & $\begin{array}{l}\text { Adj } \\
\text { MS }\end{array}$ & $P$ & $\begin{array}{c}\% \\
\text { Contribution }\end{array}$ \\
\hline $\begin{array}{l}\text { Austenitization } \\
\text { Temperature }\end{array}$ & 1 & 18678 & 18678 & 0.000 & 21.5 \\
\hline $\begin{array}{l}\text { Austempering } \\
\text { Temperarure }\end{array}$ & 2 & 66113 & 33057 & 0.000 & 76.2 \\
\hline Austempering Time & 1 & 187 & 187 & 0.031 & 0.2 \\
\hline Mn Content & 2 & 688 & 344 & 0.001 & 0.8 \\
\hline Error & 29 & 1059 & 37 & & \\
\hline Total & 35 & 86725 & & & \\
\hline
\end{tabular}

The results of ANOVA for tensile strength are provided in table 7. Austempering temperature and austenitization temperature contribute for $90.5 \%$ of the variations in the tensile strength of the material. The effect of Manganese is more pronounced in case of tensile strength with a contribution of $8.6 \%$ of the variations in tensile strength while austempering time has very less contribution.

The results of ANOVA for tensile strength are provided in table 7. Austempering temperature and austenitization temperature contribute for $90.5 \%$ of the variations in the tensile strength of the material. The effect of Manganese is more pronounced in case of tensile strength with a contribution of $8.6 \%$ of the variations in tensile strength while austempering time has very less contribution. 
Table 7. ANOVA results for tensile strength

\begin{tabular}{llllll}
\hline Factors & $\begin{array}{l}\text { Degrees } \\
\text { of } \\
\text { freedom }\end{array}$ & $\begin{array}{l}\text { Seq sum } \\
\text { of } \\
\text { square }\end{array}$ & $\begin{array}{l}\text { Adj } \\
\text { MS }\end{array}$ & P & $\begin{array}{l}\% \\
\text { Contribution }\end{array}$ \\
\hline $\begin{array}{l}\text { Austenitization } \\
\text { Temperature }\end{array}$ & 1 & 648293 & 648293 & 0.000 & 30 \\
$\begin{array}{l}\text { Austempering } \\
\text { Temperarure }\end{array}$ & 2 & 1313249 & 656624 & 0.000 & 60.5 \\
$\begin{array}{l}\text { Austempering } \\
\text { Time }\end{array}$ & 1 & 13885 & 13885 & 0.000 & 0.6 \\
Mn Content & 2 & 187233 & 93617 & 0.000 & 8.6 \\
Error & 29 & 4579 & 158 & & \\
Total & 35 & 2167239 & & & \\
\hline
\end{tabular}

\section{Regression models and optimization for hardness and tensile strength}

Response surface regression was used to fit an equation in order to optimize the hardness and tensile strength using the following factors: Austenitization temperature (a), austempering temperature (b), austempering time (c), and manganese content (d).

The regression equations for hardness and Tensile Strength are given in Equation (1) and Equation (2) respectively.

$$
\begin{gathered}
\text { Hardness }(B H N)=1111.64-0.455556(a)-1.04667(b)-4.55556(c)-9.5294(d) \\
\text { Tensile strength }=5279.48-2.68389(a)-4.67833(b)-39.2778(c)-237.739(d)
\end{gathered}
$$

The $\mathrm{R}-\mathrm{Sq}$ values for hardness and tensile strength are $97.89 \%$ and $99.76 \%$ respectively. The $\mathrm{R}-\mathrm{Sq}$ (Adj) values for hardness and tensile strength are $97.62 \%$ and $99.73 \%$ respectively. The high $\mathrm{R}-\mathrm{Sq}$ and $\mathrm{R}-\mathrm{Sq}(\mathrm{Adj})$ values indicate that the regression equations possess a good fit to the actual experiment conducted. The equations could be used for optimization of process variables and for prediction of hardness and tensile strength at any of the intermediate values of the control variables. In Equations (1) and (2), the coefficients of all the terms are negative and hence the hardness and tensile strength will be minimum at the upper limits of the factors under consideration in the range of the study undertaken.

Optimization of the parameters using the Response Surface Optimizer based on "lower is the better" approach was carried out separately for hardness and tensile strength, as lesser hardness gives better machinability. The optimized parameters are as follows: Austenitization temperature $=950^{\circ} \mathrm{C}$, Austempering temperature $=420^{\circ} \mathrm{C}$, Austempering time $=2 \mathrm{~h}$ and Manganese content $=1.01 \mathrm{wt} \%$. The optimal parameters are upper limits of the parameters considered in the study. The values of hardness and tensile strength at the optimal process parameters from the regression equations (1) and (2) are $220.6 \mathrm{BHN}$ and 446 $\mathrm{N} / \mathrm{mm}^{2}$ respectively. The values of hardness and tensile strength at the optimal conditions 
from the experiments are $229 \mathrm{BHN}$ and $470 \mathrm{~N} / \mathrm{mm}^{2}$. The percentage variation in hardness and tensile strength between the experimental values and the values from regression equations are $3.8 \%$ and $5.3 \%$ respectively which is very less. A Pearson's coefficient of correlation between the hardness and tensile strength is 0.955 and this indicates that the change in hardness is a strong indication of change in tensile strength in the same direction.

\section{CONCLUSIONS}

In this study, microstructure analysis is carried out to understand the effects of heat treatment on manganese alloyed ADI. Response surface methodology was used to optimize the process parameters and to fit a regression equation. ANOVA was carried out to determine the relative contribution of each factor on the responses. Based on the statistical and microstructure analysis, the following conclusions are made.

- Microstructure analysis has revealed the presence of typical "ausferrite" structure. At the high austempering temperature of $420^{\circ} \mathrm{C}$, a coarser and feathery structure was obtained with higher retained austenite content which resulted in reduced hardness and tensile strength.

- $\quad$ As the austenitization temperature has been increased from $850^{\circ} \mathrm{C}$ to $950^{\circ} \mathrm{C}$, the amount of retained austenite has been increased, resulting in the marginal decrease of hardness and tensile strength.

- $\quad$ According to ANOVA results, the predominant factor affecting the hardness and tensile strength was austempering temperature with a contribution of $74.5 \%$ followed by austenitization temperature with $23 \%$ contribution.

- $\quad$ Based on the response optimization, using the "lower is the better" approach, the optimum level of process parameters for hardness was obtained as: austenitization temperature $=950^{\circ} \mathrm{C}$; austempering temperature $=420^{\circ} \mathrm{C}$; austempering time $=2 \mathrm{~h}$; manganese content $=1.01 \mathrm{wt} \%$.

- Hardness values predicted using general linear regression analyses were in close agreement with experimental values with a high R squared value of $98 \%$. 


\section{REFERENCES}

[1] Artola G, Gallastegi I, Izaga J, Barreña M, Rimmer A. Austempered ductile iron (ADI) alternative material for high-performance applications. International Journal of Metalcasting 2017; 11: 131-135.

[2] Cakir C M, Ali B, Yahys I, Baris S. The effects of austempering temperature and time onto the machinability of austempered ductile iron. Materials Science and Engineering A 2005; 407: 147-153.

[3 Rundman K B, Moore D J, Hayrynen K L, Dubensky W J, Rouns T N. The microstructure and mechanical properties of austempered ductile iron. Journal of Heat treating 1988; 5 (2): 79-95.

[4] Chang LC, Hsui IC, Chen LH, Lui TS. Effects of heat treatment on the erosion behavior of austempered ductile irons. Wear 2006; 260:783-793.

[5] Nofal AA, Jekova L. Novel processing techniques and applications of austempered ductile iron. Journal of the University of Chemical Technology and Metallurgy 2009; 44(3): 213-228.

[6] Zimba J, Simbi D J, Navara E. Austempered ductile iron: an alternative material for earth moving components. Cement and Concrete Composites 2003; 25 (6): 643-649.

[7] Kumar K M, Hariharan P, Venkateshwaran P, Tamilarasan S. Examination of microstructure and mechanical properties of austempered ductile iron (ADI) as per austempering temperature and time. Transactions of the Indian Institute of Metals 2015; 68 (1): 67-71.

[8] Han Ch F, Sun Y F, Wu Y, Ma Y H. Effects of vanadium and austempering temperature on microstructure and properties of CADI. Metallography, Microstructure, and Analysis 2015; 4 (3): 135-145.

[9] Batra U, Ray S, Prabhakar SR. Tensile properties of copper alloyed austempered ductile iron: effect of austempering parameters. Journal of Materials Engineering and Performance 2004; 13 (5): 537-541.

[10] Marcelo Vasconcelos de Carvalho, Davi Melo Montenegro, Jefferson de Oliveira Gomes. An analysis of the machinability of ASTM grades 2 and 3 austempered ductile iron. Journal of Materials Processing Technology 2013; 213: 560-573.

[11] Olawale JO, Ibitoye SA, Oluwasegun KM et al. Forced-air cooling quenching: a novel technique for austempered ductile iron production. International Journal of Metalcasting 2017; 11 (3): 568-580.

[12] Arft M, Klocke F, Lung D. Evaluation of the machining aspects of austempered ductile iron. International Journal of Metalcasting. 2012; 6 (4): 35-42.

[13] Basso A, Sikora J. Review on production processes and mechanical properties of dual phase austempered ductile iron. International Journal of Metalcasting 2012; 6 (1): 7 14.

[14] Zanardi F, Bonollo F, Angella G et al. A contribution to new material standards for ductile irons and austempered ductile irons. International Journal of Metalcasting 2017; 11 (1): 136-147.

[15] Méndez S, Urko de la Torre, González-Martínez R, Ramon S. Advanced properties of ausferritic ductile iron obtained in as-cast conditions. International Journal of Metalcasting 2017; 11 (1): 116-122. 
[16] Narasimha Murthy K, Sampathkumaran P, Seetharamu S. Abrasion and erosion behaviour of manganese alloyed permanent moulded austempered ductile iron. Wear 2009; 267: 1393- 1398.

[17] Bayati H, Elliott R. Influence of austenitising temperature on mechanical properties of high manganese alloyed ductile iron. Materials Science and Technology 1995; 11 (9): 908-913.

[18] Razak NH, Rahman MM, Kadirgama K. Cutting force and chip formation in end milling operation when machining nickelbased superalloy, Hastelloy C-2000. Journal of Mechanical Engineering and Sciences 2017; 11 (1): 2439-2451.

[19] ASTM A536, Standard specification for ductile iron castings, annual book of ASTM standards, Vol. 01.02, ASTM International, West Conshohocken, PA (2014).

[20] ASTM E8/E8M- 16a, Standard test methods for tension testing of metallic materials, annual book of ASTM standards, Vol.03.01, West Conshohocken, PA (2016).

[21] Vikas Chawla1, Uma Batra, Puri D, Amita Chawla. To study the effect of austempering temperature on fracture behaviour of ni-mo austempered ductile iron (ADI). Journal of Minerals and Materials Characterization and Engineering 2008; 7 (4):307-316.

[22] Junjun Cui, Liqing Chen. Microstructures and mechanical properties of a wearresistant alloyed ductile iron austempered at various temperatures. Metallurgical and Materials Transactions A 2015; 46 (8): 3627- 3634.

[23] Ritha Kumari U, Prasad Rao P. Study of wear behaviour of austempered ductile iron. Journal of Materials Science 2009; 44: 1082-1093.

[24] Jiwang Zhang, Ning Zhang, Mintang Zhang, Liantao Lu, Dongfang Zeng, Qingpeng Song. Microstructure and mechanical properties of austempered ductile iron with different strength grades. Materials Letters 2014; 119: 47-50.

[25] ASTM E1245-03(2016) Standard practice for determining the inclusion or secondphase constituent content of metals by automatic image analysis, ASTM International, West Conshohocken, PA, 2016.

[26] Srinivasmurthy Daber, Ravishankar K S, Prasad Rao P. Influence of austenitising temperature on the formation of strain induced martensite in austempered ductile iron. Journal of Materials Science 2008; 43: 4929-4937.

[27] Branka Bosnjak, Branko Radulovic. Effect of austenitising temperature on austempering kinetics of ni-mo alloyed ductile iron. Materials and Technology 2004; 38: 307-312.

[28] Susil K Putatunda, Pavan K Gadicherla. Influence of austenitizing temperature on fracture toughness of a low manganese austempered ductile iron (ADI) with ferritic as cast structure. Materials Science and Engineering A 1999; 268: 15-31.

[29] Manivel D, Gandhinathan R. Optimization of surface roughness and tool wear in hard turning of austempered ductile iron (grade 3) using Taguchi method. Measurement 2016; 93: 108-116. 